\title{
Индоевропейское языкознание и классическая филология XV. Чтения, посвященные памяти профессора И. М. Тронского. Санкт-Петербург, 20-22 июня 2011 г.
}

Очередная, пятнадцатая, конференция памяти профессора И. М. Тронского прошла в Петербурге в Институте лингвистических исследований РАН 2022 июня 2011. Как и обычно, доклады на конференции разделились на три неравные части (1) классическая филология (подавляющее большинство докладов), (2) сравнительно-историческое языкознание, преимущественно индоевропеистика, один доклад был посвящен хурритскому и северокавказским языкам (А. С. Касьян); (3) и отдельные диахронические исследования по конкретным индоевропейским языкам.

К сожалению, целый ряд докладчиков, подавших заявку на конференцию, не смогли выступить.

В нашей хронике мы не фиксируем доклады, посвященные чисто филологическим проблемам исследования латыни и древнегреческого. Среди лингвистических докладов были представлены следующие.

Е. П. Новикова рассмотрела в докладе «„Alii rhetorica tongent" Энния: к вопросу о раннем влиянии сельских диалектов на латинский язык» следы возможного влияния диалектов на литературный латинский язык, в основном на материале глагола tongeo. При рассмотрении латинских глаголов на -ео с корневым o, однако, совершенно недостаточно были учтены и.-е. каузативы, которые идеально объясняют данные глаголы. Сам латинский тип упоминается автором всколь, оценивается как «непродуктивный и неиндоевропейский» и далее в рассмотрение не принимается. Если бы автор учел хоть одну работу по и.-е. глагольной морфологии за пределами стандартных этимологических словарей, объяснение tongeo получилось бы куда более простым без огромного количества допущений (не подтвержденных материалом) о влиянии оскских диалектов (не тождественных засвидетельствованным!) на латынь.

А. М. Белов в докладе «О законе Вандриеса в системе древнегреческой баритонезы» предпринял попытку переформулировать закон Вандриеса. Суть переформулировки состоит в том, что вместо переноса ударения со второго слога на третий А. М. Белов предлагает скорее говорить о тенден- ции передвижения ударения к началу слова («дальней баритонезе»). Особые маркированные случаи сохранения ударения в окситонезе и ближней баритонезе должны быть объяснены рядом причин морфологического и морфонологического характера. В последовавшей необычайно оживленной дискуссии были высказаны серьезные возражения против такой переформулировки.

С. И. Дмитриева в докладе «Глаголы с суффиксом *-ske/o-, образованные от основ на смычный в древнегреческом языке» рассматрела некоторые архаичные глаголы данного класса. Не вполне понятным осталось ограничение круга глаголов только основами на смычный, фактически четырьми глаголами. Собственно, с синхронной точки зрения суффикс -ske/o- в данных глаголах не выделяется. Поэтому ничего удивительного нет в том, что, как отмечает автор доклада, грамматическая семантика суффикса неочевидна. Это же объясняет и часто представленную перфективность некоторых глаголов. В терминологическом плане не совсем понятно, зачем говорить отдельно о хабитуальном значении и генерализованном контексте.

А. А. Евдокимова в докладе «Греческие граффити из собора Софии Константинопольской» впервые публикует 10 новых кратких граффити из храма Святой Софии. Их значение для истории греческого языка достоточно ограничено.

С. Р. Тохтасьев в докладе «Редкий тип склонения антропонимов в боспорских надписях» подробнейшим образом проанализировал редкий тип склонения антропонимов, который он считает импортированным на Боспор из Македонии и Фракии.

Сравнительно-историческое языкознание за пределами сравнительно-исторического исследования латыни и древнегреческого было представлено на конференции преимущественно индоевропеистикой. Однако были также отдельные доклады, посвященные другим языковым семьям. Так, доклад А. С. Касьяна «Некоторые соображения о лексических схождениях между хурритским и северокавказскими языками» рассматривает три заимствования в сфере базисной лексики из хурритского в 
пранахский. В докладе отвергается гипотеза о родстве хуррито-урартских языков с северокавказской семьей.

Среди докладов, посвященных классической индоевропеистике, выделялся доклад Х. Айхнера «Представления индоевропейцев о загробной жизни». В нем вновь рассматривалось сопоставление индийской собаки Шабала с Цербером. На этом основании реконструируется *k'erwero-, обозначавшее особый окрас собаки. Также разбиралось соответствие индо-иранского повелителя потустороннего мира Үama, латв. Jumis и герм. Ymir.

В рамках классической европейской индоеропеистики был также выполнен доклад К. Аккерманн «Observations on the IE roots with the potential *-bh extention».

Доклад Ю. К. Кузьменко «Формирование протогерманского языка. Генетика и лингвистика» рассматривал достаточно традиционную проблематику - сравнение инноваций, которые характеризуют протогерманский и итало-кельский, с одной стороны, и протогерманский и балто-славянский, с другой, а также учитывал фонологические инновации, общие для протогерманского и протофинно-саамского и лексическе заимствования из неизвестного субстрата - в свете генетических данных о формировании германского этноса.

В докладе А. В. Шацкова «Хеттские имперфективы на anna/i-» разбирались некоторые аспекты употребления данного имперфективного суффикса, в частности устанавливалась корреляция между залогом глагола и суффиксом: подавляющее большинство глаголов, образующих имперфективные формы с этим суффиксом, принадлежат к среднему залогу. Также была разобрана этимология суффикса.

П. А. Кочаров в докладе «Грамматическое значение древнеармянских основ настоящего времени на -u-» рассмотрел употребление презентных основ на - $u$ - в классическом древнеармянском языке в сравнении с другими суффиксальными презент- ными основами. Отмечается, что основы на -и- чаще оформляют переходные действия с минимальной эмоциональной вовлеченностью агенса, такие как «лизать», «молоть», «стричь».

Нечеткой методологией и небрежностью сопоставлений армянского материала с анатолийскими, а также другими и.-е. данными был, к сожалению, отмечен доклад Б. С. Зулумян «Об армянском боге Тире».

Среди докладов по конкретным и.-е. языкам, выполненным вне компаративного метода, были представлены следующие.

О. В. Каменева «К вопросу об употреблении союзов гот. jabai и ip в условных конструкциях вида casus irrealis». Н. А. Бондарко в докладе «Неизвестный фрагмент трактата Давида Аугсбургского «Formula de compositione hominis exterioris ad novitios» из собрания РНБ» описал рукопись Нем.Q.I.310 из собрания РНБ и опубликовал перевод одной из глав трактата Давида Аугсбургского вместе с латинским оригиналом.

А. В. Сидельцев в докладе «К диахронической типологии местоименной репризы: хеттские параллели к балканской местоименной репризе» рассматривал фрагмент универсальной типологии местоименной репризы - соотношение хеттской и балканской моделей.

А. Р. Зиновьева в докладе «Гетероглоссия в „Глиняной повозке“: почему хозяин театра говорит на разных языках?» рассмотрела феномен гетероглоссичности индийской драматической традиции на примере реплик хозяина театра в драме Шудраки.

В рамках конференции было также проведено заседание, посвященное 300-летию М.В.Аомоносова, однако подробное рассмотрение докладов подобной тематики выходит за пределы тематики данного журнала.

Материалы конференции, как всегда оперативно и качественно, были опубликованы до начала конференции. 